\title{
HERITAGE AFFECTATION CONSIDERATIONS
}

\author{
Carmen Teodora Popa \\ Department of Law, Faculty of Law, University of Oradea, Oradea, Romania \\ bnppopacarmen@gmail.com
}

\begin{abstract}
The present work intends to analyse the institution of affected heritage in the light of the rules and regulations of the civil code and the special laws. The constitution of an affected patrimony intended for the exercise of a profession or of the operation of an enterprise, constitutes a useful tool for legal professionals and separation from the rest, marks the separation from the rest of the assets and liabilities that constitute the guarantee of the general creditors of the person undertaking the physical authorized holder or individual members of the family enterprise.
\end{abstract}

Keywords: professional patrimony, patrimony of affection, Civil Code, professional.

JEL classification: $\mathrm{K} 15, \mathrm{~K} 11, \mathrm{~K} 40$.

\section{Introduction}

The notion of patrimony of affection was enshrined in Romanian civil law and before the adoption of the New Civil Code (Law nr.287/2009, The Civil Code). Thus, the special normative acts regulating the liberal professions contain provisions regarding the special destination which can be obtained from the patrimony of these persons, as an estate patrimony, goods used for the exercise of the profession and for the satisfaction of creditors whose claims were born within the exercise of the profession (Bârsan, 2013:13). For example, art. Article 64 letter h of Law no.95/14.04.2006 on healthcare reform, as amended, defines the occupational property patrimony as the totality of the property, rights and obligations of the physician affected for the purpose of exercising his profession, constituted as a distinct fraction of the physician's patrimony, separated from the general pledge of its creditors.

Based on these premises that were already in the legislation, the civil code entered into force on 01.0.2011 regulates the legal status of the affected heritage in a new vision, only at the level of a principle, having already enshrined the concept of patrimony of affection through special laws.

Under the Civil Code, all who exploit an enterprise are considered to be professionals. Exploitation of an enterprise means the systematic pursuit by one or more persons of an organized activity consisting in the production, management or disposal of goods or the provision of services, whether or not it has a lucrative purpose.

Thus, by a professional is meant both the legal person carrying out activities of the type mentioned above and the natural person classified into the following categories:

a) entrepreneur, trader or economic operator, a person carrying out an activity authorized by law - these persons are registered in the Trade Register and their activity is regulated by O.U.G. no.44 (2008) on the carrying out of economic activities by authorized natural persons, individual enterprises and family enterprises;

b) the person who independently carries out a liberal profession authorized by law, a profession which has its own regulation in a special law. This category includes persons carrying out professions such as notaries, lawyers, bailiffs, financial auditors, architects, 
physicians, insolvency practitioners, accountants, etc., who carry out their profession either independently or in the careers, but in both cases legal personality.

A person may carry out an economic activity as the holder of an authorized individual under O.U.G. no.44 (2008) on the carrying out of economic activities by authorized natural persons, individual enterprises and family enterprises (Cărpenaru, 2012:38). According to this ordinance, the subjects of law under it have a property patrimony consisting of the totality of the goods, rights and obligations, affected by the purpose of exercising an economic capacity which are intended, constituted as a distinct fraction of the natural person's authorized patrimony, of the holder of the individual enterprise members of the family business.

According to art. 31 Civil Code (2009), any natural or legal person is the owner of a patrimony that includes all the rights and liabilities that can be valued in money and belong to it. Therefore, the natural or legal person has only one patrimony, regardless of whether it is the subject of a division or an affair (Stoica V., 2013: 14).

\section{The legal regime of the patrimony of affection}

The patrimony of affection is not an original patrimony, but a patrimony created by the general patrimony, by the will of its owner, in cases authorized by law. It results thus, that the general patrimony is the creation of the law, while patrimonial affection is the creation of the owner of the general patrimony (Tuleașcă, 2017). Starting from this idea, the doctrine expressed the opinion that the patrimony of affection is not an attribute of personality, because a person can decide whether or not to constitute a patrimony of affection.

The patrimony of affection, as a fraction of universality, is a juridical universality which contains rights and obligations linked to the purpose of their affection, created by the exclusive will of the owner of the general patrimony and recognized by the law.

The entrepreneur has a general patrimony in which one or more distinct patrimonial masses can be formed, termed patriots of affection, for the purpose of achieving a certain purpose. In this situation, the general heritage (gender concept) is divided into patrimony of affection and personal patrimony (species), both of which are included in the general patrimony of the entrepreneur. The establishment of the patrimonial mass necessary for the defrauding of the entrepreneur's activity shall be established by the act concluded by the holder, in compliance with the conditions of form and publicity stipulated by the law. Subsequent to the creation of this patrimony of affection, it is possible to increase or decrease it, which can also take place through a unilateral legal act. A single restriction is foreseen in the same situation, namely not to prejudice the rights of creditors on each patrimonial estate.

The general rule is that creditors whose debts were born in connection with a particular patrimony division authorized by law must first pursue the property which is the subject of such property, and if they are not sufficient to satisfy the claim they will could track the other assets of the debtor. The rule applies to the persons listed in letter a above.

By way of exception, persons who carry out independently a liberal profession authorized by law (the letter b) will be limited in the sense that the assets belonging to the patrimonial property will be traced only to the creditors whose debts were born in relation to that profession. These creditors will not be able to track the other assets of the debtor even when their claim is not covered by the execution of the assets that are part of this patrimonial mass (Șchiau, lonaș-Sălăgean, 2016:17).

Thus, the personal creditors of a professional whose claim was not born in connection with the expulsion of his undertaking or in connection with the pursuit of the profession authorized will not be able to pursue, in order to satisfy his claim, those goods which are included in the patrimony of affection. This principle is enshrined in art.2324 paragraph 4 of the Civil Code regarding the situation of the authorized professionals who constitute their patrimony. If the professional is not a property patrimony, goods affected by the exercise of the profession or 
occupation of the individual debtor may be subject to enforced prosecution only if there are no traceable assets, and only for maintenance obligations or other privileged claims on movable property.

\section{National Register of Patrimonial Masses (RNPMP)}

At the level of the National Union of Notaries Public, the National Register of Patrimonial Matters for the Occupation of the Occupation (RNPMP) was set up relatively recently. The administration of this Register belongs to the National Center for the Administration of Notarial National Records- Infonot (CNARNN-INFONOT). This register has the object of opposing third parties in establishing the patrimony of affection.

Thus, the acts by which professionals constitute their patrimony, as well as those by which changes are made either in the sense of enlargement or in the sense of diminution, shall be entered in this register.

If the professional started his activity after the new Civil Code entered into force, it is obligatory to draw up the constitutive act of the patrimony of affection. It is possible, however, to enrol in this register and the professional who started his activity before the entry into force of the Civil Code.

In conclusion, any person who carries out an authorized profession, individually or in association, will be able to request, at any time of the start of the activity, the registration in the RNPMP. The act by which the patrimony is constituted or modified will be a pre-constituted means of proof, to which any subsequent action against the professional may be reported. As a result, its creditors will not be directed to other assets belonging to them, but are not included in this table.

Instead, if the occupational patrimony does not appear high, creditors will be able to claim that it includes all the assets belonging to the debtor. The following documents are required to enter the RNPMP:

- evidence of the exercise of the profession, individually or in the association;

- the attestation that the professional appears in the records of the professional body to which he belongs;

- the constitutive act, the amendment act or at least an inventory where the asset and liability items are highlighted.

The act of incorporation of the patrimony of affection can take the form of the document under private signature, not being the authentic form for enrolment in the RNMPP.

\section{The transfer of ownership of an asset in the affected heritage assets}

The transfer of the property right over a property in the patrimonial mass affected by the patrimony does not constitute an alienation (according to art. 32 of the Civil Code) as it will not leave the natural person's patrimony but will pass from one patrimony to another.

The authorized individual, the individual enterprise or the family enterprise do not have legal personality within the meaning of the Civil Code. In this regulatory context, the authorized person is a form of economic activity organized under the law by a natural person who can not be part of a sale-purchase contract.

\section{Conclusion}

In conclusion, if the authorized person purchases a real estate, for example, and the price of the property is paid out of the natural person's property, a party to the sale-purchase contract will be the natural person and the notary will make a mention in the contract sale-purchase that the asset is part of the physical patrimony of the individual. 
Regarding the registration in the land book, it is ordered the registration of the property right in favor of the natural person, together with the marking of the property belonging to the patrimony of affection related to the exercise of an authorized profession - authorized individual/individual enterprise/family enterprise, under art.33 par.1 Civil Code (The National Union of Notaries Public from Romania 2017, p.156). In this regard, we mention the provisions of Article 171 point 4 of Order 700 (2014) regarding the approval of the Regulation for the approval, reception and registration in the cadastre and land registry documents issued by the National Agency for Cadastre and Real Estate Advertising, according to which the transfer of a real estate right from a patrimony to a patrimonial mass belonging to authorized natural persons, to individual enterprises, family enterprises or other similar entities without legal personality, shall be made in the table for the titular physical person and shall mention the membership in this mass heritage.

\section{References}

Cărpenaru, St. (2012) Tratat de drept comercial roman (Romanian Commercial Law Treaty), București: Editura Universul juridic.

Bârsan, C. (2013) Drept civil. Drepturile reale principale în reglementarea noului Cod civil (The Civil law. The main real rights in the regulation of the new Civil Code), București: Editura Hamangiu.

Schiau, I. and lonaș-Sălăgean, M. (2016) Despre patrimoniul de afectațiune profesională (The professional heritage of affectation), Revista Română de drept al afacerilor no 6, pp.15-22.

Stoica, V. (2013) Patrimoniul de afectațiune - continuitate și reformă (Heritage of affectation - continuity and reform), Revista Română de drept privat no 2., pp. 13-23.

Tuleașcă, L. (2015) Despre (ne)executarea patrimoniului de afectațiune (About the execution (or non) of the patrimony of affection), Revista Română de Executare Silită no.2. Tuleașcă, L. (2016) Patrimoniile de afectațiune și teoria personalistă a patrimoniului (The affectation patrimony and the heritage personalist theory), available from http://www.magazinuljuridic.ro/patrimoniile. [31.08.2017].

The National Union of Notaries Public from Romania (2017). Collection of notary practice in the field of cadastre and real estate advertising, vol. II, București.

The National Union of Notaries Public from Romania (2011), Codul civil al României. Îndreptar notarial, Bucuresti: Editura Monitorul Oficial.

Law nr.287/2009 The Civil Code, Monitorul Oficial no. 505, July $15^{\text {th }} 2011$

Law no.95/14.04.2006 on Healthcare Reform, Monitorul Oficial no.372, April $28^{\text {th }} 2006$.

O.U.G. no.44 / 16.04.2008 on the carrying out of economic activities by authorized natural persons, individual enterprises and family enterprises, Monitorul Oficial no.328, Aprilie $25^{\text {th }}$ 2008.

National Agency for Cadastre and Land Registration, Order no 700/09.07.2014 regarding the approval of the Regulation for the approval, reception and registration in the cadastre and land registry.

\section{Bio-note}

Carmen-Teodora Popa has been an academic and researcher at the University of Oradea, Faculty of Law, since 1998, currently being Associate Professor. Since 2007, she is also an active member of The National Union of Notaries Public from Romania. Her research focuses on topics related to Civil Law, Succession Law and Special Contracts, and Commercial Law. 